\title{
Hydrochemical and Hydrogeological Impact of Hydraulic Fracturing in the Karoo, South Africa
}

\author{
G. Steyl and G. J. van Tonder \\ Additional information is available at the end of the chapter
}

http://dx.doi.org/10.5772/56310

\begin{abstract}
Hydraulic fracturing has become a prevalent public and regulatory issue in most countries developing shale gas. South Africa has only recently been exposed to terrestrial gas resource development and this has created unique regulatory issues which are currently being resolved. One of the key issues under debate is the protection of groundwater resources in rural areas, since most of South Africa's rural and some inland cities are dependent on groundwater for potable water supply. A second concern is the infrastructure requirements to handle the material movement processes during the development of each wellfield and subsequent processing of waste generated on site. Regarding the waste material production, a phased approach is required which considers the initial well development activities, production and subsequent well abandonment. Each phase has a unique risk associated with it and thus would require different management options. At the current stage most of the focus is on the initial stages of well development but the long term view has been neglected to some extent. Due to the unique geological structure of the Karoo, the presence of dolerite structures, a number of risk mitigation methods might be required to succesfully develop hydraulically fractured wells. In all aspects the chemical and hydrogeological impacts related to wellfield development cannot be ignored in the Karoo aquifer system, as it may directly influence human and environmental health. This paper will present chemical perspective on the hydraulic fracturing perspective that will deal with the impact of hydraulic fracturing fluid and flowback water. Additionally, the interaction of wellfield development and hydrogeology of the Karoo area will be discussed and how it relates to future water quality issues.
\end{abstract}

Keywords: Hydraulic fracturing, hydrochemistry, hydrogeology, impact 


\section{Introduction}

This paper attempts to summarize the current knowledge on hydraulic fracturing and production issues related to shale gas in South Africa. The observation and findings made in this work is neither totally comprehensive nor exhaustive since no data is available in the public domain on hydraulic fracturing and it associated activities in South Africa. The exploration for natural gas resources in terrestrial South Africa has been conducted since the mid-1960's, however no exploitable source could be located. Limited gas was however found in the tight shale formations of the Ecca Group at an approximate depth of 2000-4000 metres below surface. The potential current shale gas reserve in the Karoo shales is estimated to be 485 trillion cubic feet, which would make it the fifth largest shale gas field in the world [1]. In geological terms the Karoo Supergroup refers to an extensive geological sequence (100-260 million years old) which consists of sedimentary and igneous rocks. Most of the Karoo Supergroup is located in South Africa and the Great Karoo has an area of more than $600000 \mathrm{~km}^{2}$.

Due to present energy shortfall in South Africa, the requirement for new energy sources have gained new momentum and part of this new focus is on shale gas in Karoo type formations. The most interesting aspect of this is that the area available for natural gas development is substantially larger than just the Karoo, with exploration areas covering six of the nine provinces in South Africa [2]. The development of shale gas resources was initiated in late 2009 but were halted due to a moratorium in early 2011. This has subsequently been lifted in September 2012. There are currently five pending applications related to exploration in the Karoo (Figure 1), three belong to Shell and one each to Falcon Oil and Gas and Bundu Gas and Oil Exploration [3]. To the north is located the petrochemical group Sasol gas exploration area, however plans have been put on hold by the company until further notice. An exploration area has also been awarded to Anglo American adjacent to the Sasol area (Figure 1).

Hydraulic fracturing was developed in the United States of America in the late 1940's to assist in the stimulation of oil and natural gas wells [4-6]. The number of wells that incorporates hydraulic fracturing increases by the day since oil and gas production is increased by this technique [5].

\subsection{Development of shale gas in South Africa}

The Shale Gas project aims to target the carbonaceous shales of the Ecca and Dwyka Groups, but the stratigraphic units in question vary in lithological makeup along strike as one proceeds from the Cape to the Free State/Natal (KZN) regions. The initial reasoning was to only target zones of the Whitehill formation of the lower Ecca, which is a carbonaceous shale unit characterized by its distinctive white weathering in outcrop. The distribution of the Whitehill Formation with its marine setting led to further investigation into the dynamics of the Main Karoo Basin and other stratigraphic units equivalent to the Whitehill to extend the potential target areas [2]. A revised set of source rocks were identified with the main target zone now being identified as carbonaceous shales of the Lower and Upper Ecca Group with subordinate interest in the Dwyka Shales (Figure 1). The source formations have been extended to include the following: 
1. Whitehill Formation (Cape region)

2. Prince Albert Formation (Cape region)

3. Volksrust Formation (Free State and KZN regions)

4. Vryheid Formation (Free State and KZN regions)

5. Pietermaritzburg Formation (Natal region)

6. Dwyka Shales (All regions, where shallow enough).

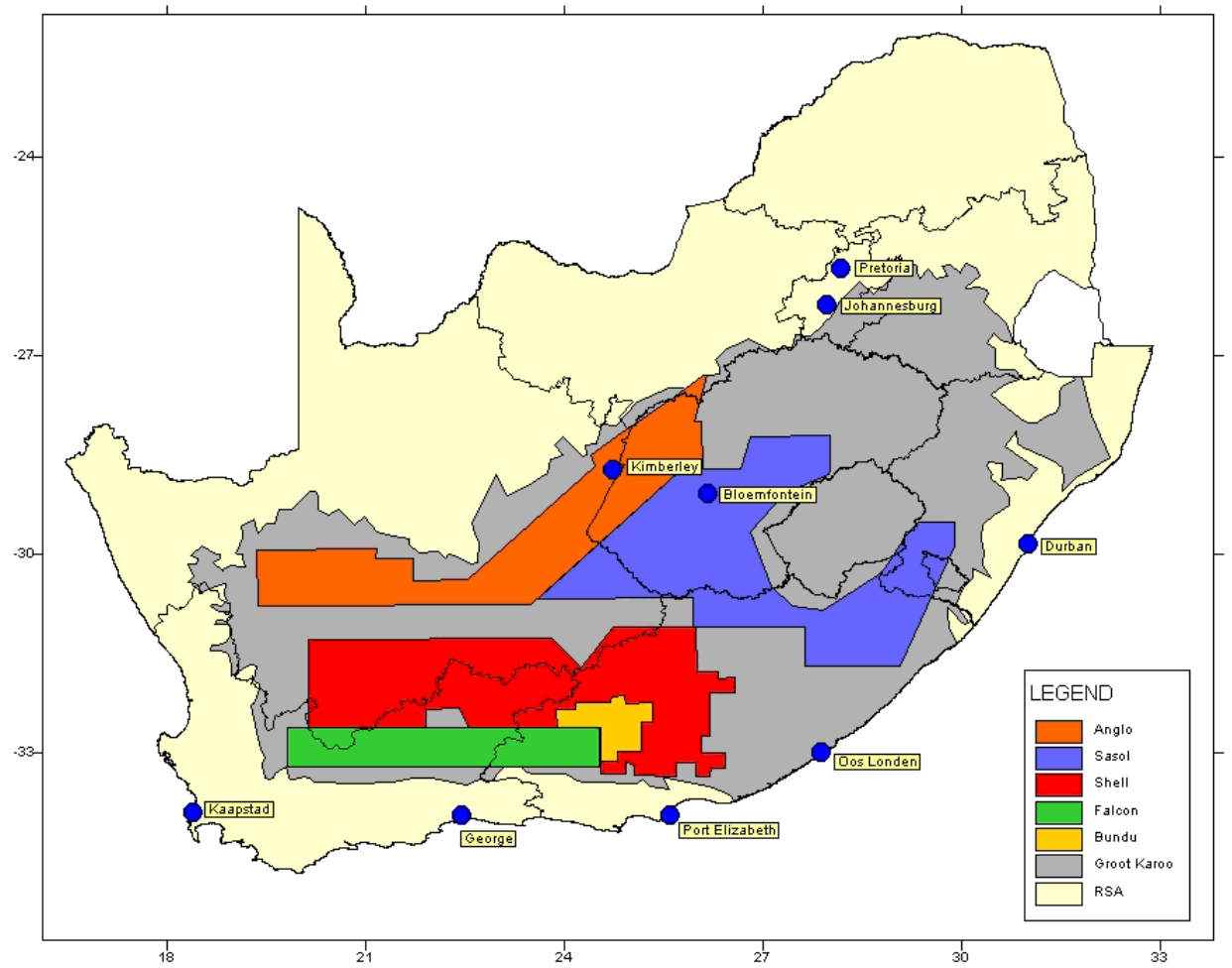

Figure 1. Regional map of South Africa, showing the exploration rights and companies associated with these permits [2].

The research into the Shale Gas deposits of the USA led to a revised set of geochemical and petrophysical parameters that are based on the criteria set by Jarvie [2] to include the following:

1. Total Organic Carbon and its composition (dead carbon, free gas, etc.) $\rightarrow 1 \%$ or more.

2. Kerogen Type $\rightarrow$ Determines hydrocarbon types as well as adsorption/desorption properties. 
3. Vitrinite reflectance and Tmax (maximum temperatures that rocks were subjected to during hydrocarbon production) $\rightarrow$ Thermal Maturity with reflectance values of 1.35-2.5, Tmax values vary and can be very high (between $400^{\circ} \mathrm{C}$ and $580^{\circ} \mathrm{C}$ as seen in the Barnett Shale).

4. Rock Eval Hydrogen Index $<100$.

5. Porosities and other physical properties related to gas flow.

6. Calculations of hydrocarbon generation, expulsion and retention.

From a South African perspective, the Rowsell and De Swardt's study [7] of the maturation indices pertaining to the Karoo Basin can be used to identify areas prospective for gas generation:

1. Temperature Range $\rightarrow \pm 130^{\circ} \mathrm{C}$ to $170^{\circ} / 180^{\circ} \mathrm{C}$.

2. Vitrinite Reflectance of 1.35-2.5.

3. $\mathrm{CR} / \mathrm{CT}$ Ratio of about 0.85 to 0.94 .

4. Total Organic Carbon and its composition (dead carbon, free gas, etc.) $\rightarrow 1 \%$ or more.

\subsection{Geology and gas plays in South Africa}

In South Africa, shales containing significant organic carbon are restricted to the Ecca Group of the main Karoo Basin, smaller basins in the northern part of South Africa and to the Bokkeveld Group in the southernmost part of South Africa [7]. These muds became buried and lithified over tens to hundreds of millions of years and generated various hydrocarbons with increasing depth of burial and increasing temperature (Figure 2). Between 2-4 km burial depth, oil is produced, between $4-5 \mathrm{~km}$, wet gas is produced and between 5-6 km, dry gas, including methane, is produced. Deeper burial results in low-grade metamorphism, the termination of hydrocarbon generation and the formation of graphite from the organic material. In South Africa, shales of the Bokkeveld Group have undergone low-grade metamorphism and no longer have a capacity for hydrocarbon generation. However, after comprehensive investigations it was confirmed that Ecca Group shales might have the potential to generate dry gas south of the $29^{\circ} \mathrm{S}$ [7]. Further north, the shales have been less deeply buried and have a potential for oil generation except where younger igneous dolerite intrusions have locally increased the thermal maturity leading to the generation of dry gas [7].

Total organic carbon within the shale is an important parameter, since there is a linear relationship between total organic carbon and gas content, as in the Barnett Shale in the Fort Worth Basin of Texas [9]. Thickness is also important, as most of the gas produced is from areas where the shale is between 90 and 183 metres thick [9]. However, more recently, it has become technically possible to produce gas from shale units as thin as 10 to 15 metres [10]. Within the main Karoo Basin (Figure 3), there are reports of natural gas occurrences both at surface and at intervals in the deep wells drilled by Soekor between 1965 and 1977. Furthermore, varying quantities of gas were obtained by desorbed gas analysis undertaken by Soekor on Ecca Group shale samples retrieved from the deep well cores [7]. 


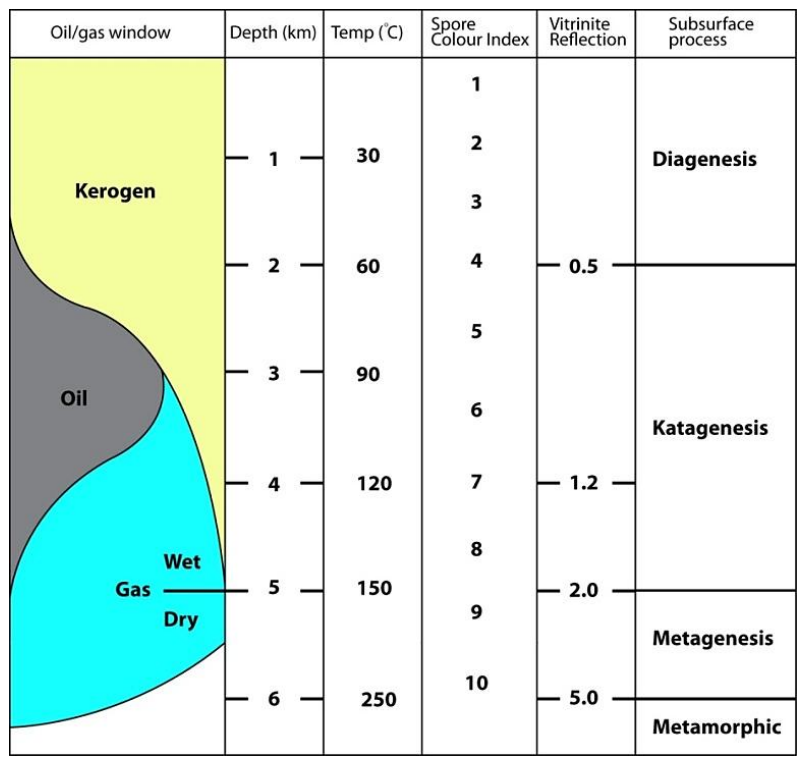

Figure 2. Hydrocarbon generation and thermal maturation indices and maturation stages plotted against depth of burial [8].

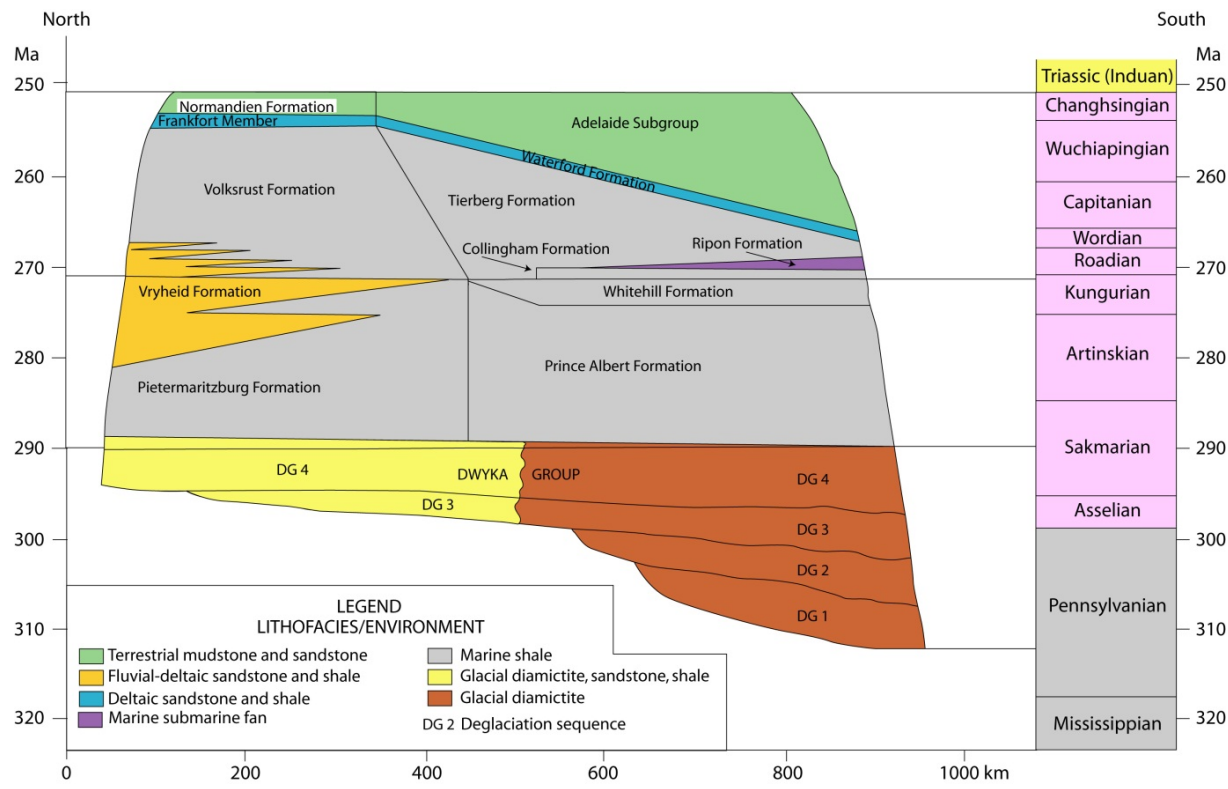

Figure 3. Distribution in time and space of the Dwyka Group, Ecca Group and Adelaide Subgroup in the main Karoo Basin, South Africa, showing lithofacies, environment and stratigraphic relationships. Modified from Fig. 7 of Veevers et al. [11]. The geologic timescale is from Gradstein et al. [12]. 
It was found that only the lower Ecca Group shales [7] within the dry gas window south of latitude $29^{\circ} \mathrm{S}$ have comparable total organic carbon contents to those of producing shales elsewhere in the USA (Table 1). The upper Ecca Group shales, namely the Tierberg Formation [13], average only 1.2 percent organic carbon [14], which is significantly lower than the 3 to 12 percent range applicable to producing shales (Table 1). The Dwyka Group also contains black shales with between 0.1 and 4.3 percent total organic carbon, averaging 1.9 percent $[15 ; 14]$. However, these shales are thin and restricted, being interbedded with diamictite and sandstone, with the thickest shales ( 50 to $60 \mathrm{~m}$ ) occurring in only 3 out of 45 deep wells investigated. The lower Ecca Group comprises black, organic-rich shale of the Whitehill Formation [16] overlying dark grey shale of the Prince Albert Formation (Figure 3) [17]. The Whitehill Formation pinches out northeastwards along a line stretching from Hertzogville in the Free State to Coffee Bay in Eastern Cape Province [14]. Northeast of this line, the Whitehill Formation correlates with the middle part of the sandstone-dominated Vryheid Formation and the Prince Albert Formation grades into shale of the Pietermaritzburg Formation (Figure 3). In the area between Coffee Bay and Harding, the Whitehill and Vryheid Formations are separated by a continuous shale succession [18].

The gas production probability was delineated by Rowsell and De Swardt [7] using the results of desorbed gas analysis on core samples from the deep Soekor wells. The gaseous hydrocarbons (methane to pentane) are absorbed on to the fine-grained constituents of shales and can be desorbed by low-temperature acid hydrolysis [7]. Samples yielding high proportions of C1 gas (methane) and C2/C1 (Ethane/Methane) relative to C3/C1 (Propane/Methane) indicate a potential for dry gas. The trend of increasing maturity due to increasing depth of burial southwards across the basin is supported by the results from other parameters, namely vitrinite reflectance, $\mathrm{CR} / \mathrm{CT}$ ratios, illite crystallinity and spore colour index. For dry gas generation, vitrinite reflectance values should be between 2 and 5 percent. In the main Karoo Basin south of latitude $29^{\circ} \mathrm{S}$, values for shale of the Ecca and Dwyka Groups vary between 1.8 and 4.4 percent [7]. Branch et al. [19] measured vitrinite reflectance values between 3.5 and 5.3 percent for shale of the Whitehill Formation and between 4.0 and 6.4 percent for shale of the Prince Albert Formation in well SA1/66 in the southwestern part of the basin some $60 \mathrm{~km}$ north of the basin margin. These correspond to the dry gas and metamorphic maturation stages, which indicates that shales in the southern extremity of the present basin are over-mature and can no longer generate dry gas. CR/CT ratios (residual, non-volatile carbon after pyrolysis to total carbon in the kerogen or organic material) gives an indication of the ability of the shale to produce additional amounts of hydrocarbons if heated to sufficiently high temperatures with lower ratios corresponding to higher potential. The results more or less correspond to the findings of the desorbed gas analysis [7]. Illite crystallinity or Kübler index is a measure of the width in millimetres of the $10 \AA$ diffraction peak at half its height. It gives an indication of the maturity level of the shale with decreasing indices corresponding to increasing maturity [7]. The results of Soekor's investigations indicate a trend of increasing Kübler index from south to north across the Karoo Basin in shales of the Ecca and Dwyka Groups. In the southern part of the basin, south of approximately $30^{\circ} \mathrm{S}$, the average indices are less than 4 and correspond to the metagenesis stage and possible preservation of dry gas. Comparative data to the Marcellus Shale and Barnett Shale is presented in Table 1. The percentage organic carbon 
detected in these shale formations in the USA are similar to those determined for the Whitehill, Prince Albert and Pietermaritzburg formations. Additionally, the thickness of the formations are also comparable to the Marcellus and Barnett shales. However, the Tierberg Formation and Volksrust Formation can also be possible future targets for shale gas exploration since these formations are considerably thicker than the USA counterparts but at a lower organic carbon content.

\begin{tabular}{lll}
\hline Unit or Formation & Percentage organic carbon (\%) & Thickness (metres) \\
\hline Marcellus Shale & $0.3-20.0$ & $12-270$ \\
\hline Barnett Shale & $0.5-13.0$ & $15-300$ \\
\hline Karoo Basin-Whitehill Formation & $0.5-14.7$ & $0.4-72$ \\
\hline Karoo Basin-Prince Albert Formation & $0.3-12.4$ & $30-500$ \\
\hline Karoo Basin-Pietermaritzburg Formation & $0.3-11.6$ & $0.8-420$ \\
\hline Karoo Basin-Tierberg Formation & $0.3-5.2$ & $400-1300$ \\
\hline Karoo Basin-Volksrust Formation & $0.3-5.9$ & $250-415$ \\
\hline Karoo Basin-Dwyka Group & $0.1-4.1$ & $0-58$ \\
\hline
\end{tabular}

Table 1. Comparative results of estimated percentage organic carbon and thickness of formation [2].

In the following sections a comparative analysis of known attributes of the Karoo shales and Marcellus Shale will be further developed as well as the impact on the hydrogeology and hydrochemical components.

\section{Problem formulation}

The major concern to date in the Karoo is the contamination of readily accessible water supply, i.e. surface water or groundwater resources. The development of an unconventional gas field does not occur in a matter of months, with a typical initiation phase of 10 years before gas production can continuously take place [20;3]. In the instance of South Africa, a number of issues restrict the development of an effective gas extraction project. The infrastructure for gas transport (pipelines) in South Africa is very limited since no conventional terrestrial gas fields exist within the borders of the country. The Soekor wells drilled between 1965 and 1977 have yielded only tentative clues to the availability of gas in the Karoo basin. In this regard the major gas companies have to do a comprehensive exploration and verification program that could last from 3-6 years depending on the geological complexity of the development area. This would be followed by a pilot study to evaluate the basic characteristics of the reservoir which can be done on a number of sites simultaniously over a period of 2-4 years. Finally, if the gas in place is adequate then the process can be developed into full production of gas which can last for 30-100 years depending on gas prices and availability within the shales. 
The geology of South Africa is quite varied considering the land size. One distinguishing feature of the geology is the presence of dolerite sills and dykes (Figure 4). The stack of sedimentary strata above the targeted formation in the Karoo consists of a succession of shale, mudrock, sandstone and dolerite. Each of these rock-types are generally characterised by low matrix transmissivities (between 0.5-50 $\mathrm{m}^{2} /$ day) [21]. These values were obtained from pump tests carried out on Karoo aquifers less than $200 \mathrm{~m}$ deep. Matrix transmissivities at greater depth would therefore be expected to be even less than these values, however this still needs to be confirmed in the future. Dolerite matrix has also been found to be quite impermeable [22] but due to the process of intrussion it can also act as an conduit. It is expected that the process of well field development would take into consideration the presence of these structures and that upward injection and production fluids would be limited.

Many of the areas where the shale formations have the potential to represent a good prospective target for exploration are also characterised by multiple dolerite intrusions. Drilling in a dolerite sill environment will face challenges that can be overcome if sufficient investigation is carried out on these intrusive structures at depth. There is sparse information on the structure of deep dolerite sills and associated deep groundwater and water strikes in the Karoo lithostratigraphic formations. All available data comes from groundwater exploration drilling at shallow to medium depth $(<300 \mathrm{~m})$. Several ground water strikes were intercepted at that depth [2]. Below this depth, the presence of deep water strikes in the Karoo formations and associated dolerite, their yields and the composition of the water are still a matter of debate.

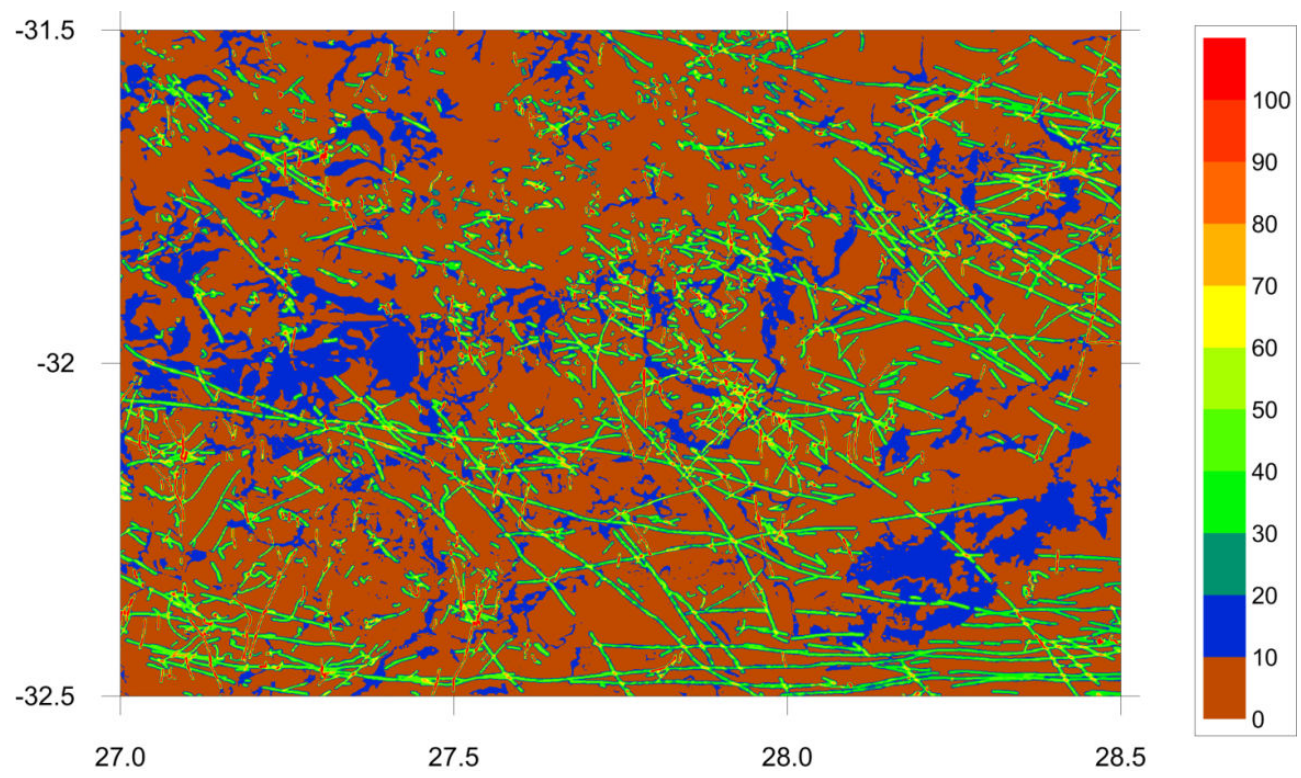

Figure 4. A regional map showing a subsection of the Karoo Supergroup with blue patterns indicating sills while green to red represents dykes in the area [2;23]. 
The key question is: Can dykes act as vertical conduits for groundwater flow or hydraulic fracturing fluids? From current literature available [2; 23], it is clear that many water strikes occur between 0-70 metres below ground level (i.e. in the weathered zone) and are found at the contact dyke-sediment. Below 70 metres the water strikes are found along transgressive fractures. The main mechanism of flow dynamics at depth and around dykes is associated with sub-horizontal fractures. These fractures are not linked to one another and collect water from the matrix (dual porosity medium). The influence of dolerite dykes on vertical groundwater circulation at depth seems therefore to be limited, but cannot be excluded due to limited data availability. The T-values from different case studies also show that permeability of the dykes is too low to allow for major flow in the dykes themselves [24].

However there is evidence of a natural connection between deep groundwater systems and the surface, as evidenced by sixteen naturally occurring warm water (thermal) springs $\left(26-41^{\circ} \mathrm{C}\right)$ in the main Karoo Basin south of latitude 28 degrees $[25 ; 26]$. These waters originate at a maximum depth of between $450 \mathrm{~m}$ and $1150 \mathrm{~m}$, as calculated from the geothermal gradient and the surface temperature of the waters. All the waters are according to Kent [25] are originally meteoritic and mainly deviate in composition due to differences in different compositions of the different rock lithologies associated with the spring, indicating also the presence of connate water. The waters of the central and eastern Karoo have $\mathrm{NaCl}$ as the prominent constituent with total dissolved solids ranging from $480-780 \mathrm{mg} / \mathrm{l}$. A few springs are, however characterised by high $\mathrm{NaHCO}_{3}$ and $\mathrm{SO}_{4}$ contents, e.g. Stinkfontein, south of Beaufort West and the spring at Cradock. Biogenic methane is one of the main gases commonly associated with the hot springs in the main Karoo Basin and in some instances constitutes the only gas present. The other gases present are mainly $\mathrm{H}_{2}, \mathrm{~N}_{2}$, $\mathrm{He}$ and $\mathrm{Ar}$ [25].

Currently within popular literature hydraulic fracturing and well field development is grouped together under the phrase of fracking. This is clearly incorrect as gas companies refer to fracking as the process of hydraulic fracturing of the formation (shale or gas containing strata) for the purpose of increasing the porosity and permeability of the system to extract shale gas. In order to effectively evaluate the risks associated with hydraulic fracturing, it is best to assess the whole process in which an unconventional shale gas well is developed. This will include the drilling, hydraulic fracturing, well completion, production phase and post closure of the well field itself.

\section{Results and discussion}

Due to the lack of current data on the Karoo (Permian), secondary sources are required to infer possible issues in this area. Firstly, to assist in the investigation international studies were required for a comparative basis to describe the influence of shale gas development programs. These areas included the Marcellus (Devonian, Pennsylvania), Antrim (Upper Devonian, Biogenic, Ohio) and Barnett (Mississippian, Texas) shale plays. These were selected due to their state of unconventional gas development and regulatory framework. One report that has recently been made available for public scrituny that contains some measurement data has 
indicated some interesting trends [27]. The report summarises both sampling from vertical and horizontal drilled wells and reports a full range of chemical and flow data. In addition to this report it was also required to evaluate the hydraulic fracturing fluid composition used in the stimulation of the shale gas well. Since it is uncertain what specific set of chemicals will be used in the hydraulic fracturing event, it was deemed the best possible solution to assess the generalised composition of these fluids. In regard to hydraulic fracturing process it should be kept in mind that although it is referred to as a single process it consists of multiple steps. Each step has a purpose in the hydraulic fracturing event as well as the transport of the propanant down the hole.

\subsection{Hydraulic fracturing process}

Considering the chemicals used during the hydraulic fracturing process, recent publication of hydraulic fracturing fluid compositions has significantly increased the transparency in the use of these chemicals [28; 29]. However, when examining the reported values in the component information disclosure, some reports indicate that there is still some components that are not listed and are most likely proprietary [30]. In the current paper only a single hydraulic fracturing composition is considered, i.e. gel hydraulic fracturing fluid. A number of hydraulic fracturing fluid setups does exist which can either be based on water (slick water), gel, hybrid, foam or gas (air, inert or petroleum gas). The type of hydraulic fracturing fluid used is dependent on a number of factors and service company preference [28].

A recent investigation by the House of Representatives in the USA [31] found that a list of 750 chemical compounds were used from 2005 to 2009. A number of chemical compounds that have been reported, included 29 chemicals that are known or possible human carcinogens and are regulated under the Safe Drinking Water Act or listed as hazardous air pollutants under the Clean Air Act [31]. BTEX compounds-benzene, toluene, xylene, and ethylbenzeneappeared in 60 of the hydraulic fracturing products used between 2005 and 2009. The hydraulic fracturing companies injected 43.1 million litres of products containing at least one BTEX chemical over the five year period. In many instances, the oil and gas service companies were unable to provide the Committee with a complete chemical makeup of the hydraulic fracturing fluids used [31]. Between 2005 and 2009, the companies used 355 million litres of 279 products that contained at least one chemical or component that the manufacturers deemed proprietary or a trade secret [31]. The practice of using BTEX is currently being phased out due to known issues [31].

Interestingly, most of the chemical components of hydraulic fracturing fluids can be described as either LNAPLs and DNAPLs from a South African context. In addition regarding the interpretation of the Water Act of South Africa, an unwanted consequence may result from the process of hydraulic fracturing. Most notably the process increases the permeability and hydraulic conductivity of the zone that is fractured. This in part can constitute an aquifer at a substantial depth from surface, in this instance it would be regarded as a controlled activity with a host of requirements that needs to be addressed to satisify regulatory practice. 
By means of an illustrative example it is possible to get a rough estimate of the extent of chemical usage in hydraulic fracturing. It has been stated that a vertical hydraulic fracturing process requires $1 \times 10^{6}$ litres of fluid; in contrast a single horizontal hydraulic fracturing process requires $10 \times 10^{6}$ litres of fluid. A pamphlet recently released by Energy in Depth gave a generic summary which stated the percentage composition of hydraulic fracturing fluid as reported by the Department of Energy [32]. If these values are taken as a lower limit then the following deductions can be made from Figure 5. Water and sand component of the hydraulic fracturing process constitutes $99.51 \%$ of the total volume used.

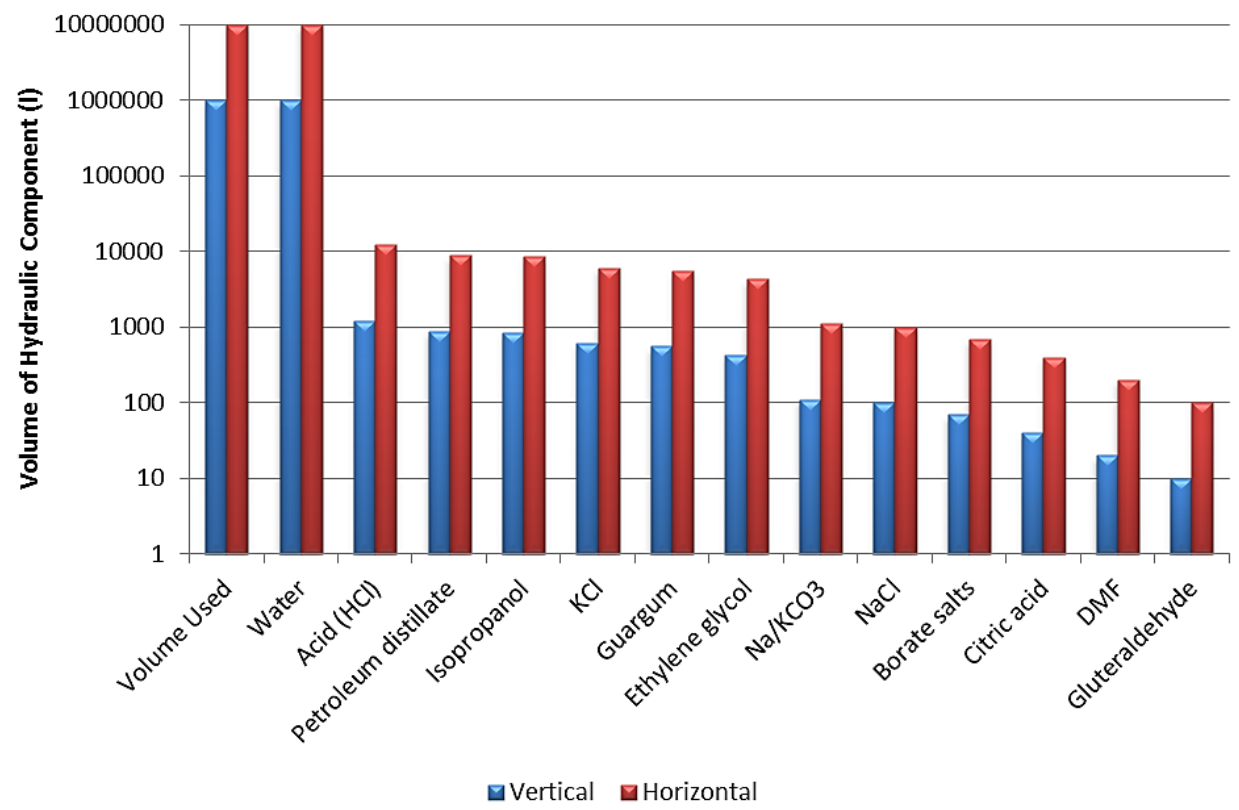

Figure 5. Generalised volume of hydraulic fracturing component used in well stimulation. Vertical well and horizontal well is indicated in blue and red bars, respectively.

Additives employed in the vertical or horizontal fracturing is present in scales approaching tonnes. Chemicals that are of special concern in large quantities are the acid phase, petroleum distillate and isopropanol. The acid phase is composed of hydrochloric acid (10-15\%) and is usually part of the first phase of fluids to be injected into the well. The main aim of the acid phase is for cleaning the perforations and initiating fissures in the near-wellbore rock (acidetching). A secondary consequence is that the acid injected does interact with the host rock formation which can mobilise certain metals, but the mobilisation is dependent on acid concentration and exposure to host rock formation [33]. Petroleum distillates and isopropanol is listed chemicals of concern (carcinogens, SDWA regulated chemicals and hazardous air pollutants in the USA) and is still used in hydraulic fracturing activities $[31 ; 28 ; 30]$. Other 
chemicals that are also classified as chemicals of concern are ethylene glycol, dimethyl formamide (DMF) and hydrochloric acid. If these components are added together more than 3410 and 34100 litres of chemicals of concern is injected into a well to develop a vertical or horizontal hydraulic fractured well, respectively. These values represent a single hydraulic fracturing event and the whole process is repeated if another section is hydraulically fractured in a well. It is important to note that it is assumed that the additives represent $0.49 \%$ of the total volume, but it can be as high as $5 \%$ in some instances, depending on field circumstances (geology, depth, anisotropic stress, water content and stability).

At this stage the most significant threat that hydraulic fracturing fluid can pose is an uncontrolled spill at surface [34]. This is due to the fact that once the hydraulic fracturing fluid has been injected into the subsurface, it reacts with the specified target components as well as the geological formation and subsurface water it comes into contact with. It is at this stage that the hydraulic fracturing fluid can undergo a number of chemical and physical processes to either precipitate, mobilise, react or undergo physical transformations (adsorption and absorption). In either instance the chemical component has been altered.

However, with current internal practices developed in the gas companies the likelihood of an uncontrolled spill have been significantly reduced. It is generally in the companies own best interest to minimise these events as it can affect future gas development rights and litigation. Spills that do occur on site is usually dealt with immediatly or a remediation plan is put into place [34].

\subsection{Backflow event after hydraulic fracturing}

The current section is focused on a report produced by Hayes [27] for the Marcellus Shale Coaliton. It is one of the few publically available documents that give an indepth report on injected and produced water in a hydraulic fractured well system. The report is used as an illustrative example and it is recognised that the water qualities associated with the Karoo Supergroup will most likely differ. It should be noted that although flowback water is used in this section, that there is no decernable difference between the classification of flowback water and produced water (Table 2). Instead it is an artificial deliniation depending on who has currently control of the site, i.e., hydraulic fracturing team or the production team. Additionally, this section will be used to illustrate the mass of salt produced from these well systems, which in turn would indicate treatment requirements and disposal volumes. It is assumed that the salt will be present as a dry material that would be disposed of in an environmentally approved manner. From a South African perspective, the most likely development of gas well fields will be multiple wells on a single pad. This is due to infrastructure requirements and safety considerations.

The average flowback percentage of vertical and horizontal hydraulic fracturing wells are $43.7 \%$ and $25.3 \%$, respectively. In Table 2 the average hydraulic fracturing volume used for vertical and horizontal wells are 5.8 million litres and 13.7 million litres, respectively. This would indicate that more than $50-70 \%$ of the fluid injected has been absorbed by the formation. In either instance it does represent a potential source of produced water over time and it is 
unclear from present data what the potential might be. Factors that could influence the production of water in shales is the current hydrogeological environment of the shale formations, i.e. hydraulic head (pre-hydraulic fracturing), hydraulic conductivity (pre-hydraulic fracturing), porosity and storativity.

In the remainder of this paper the focus will be on the horizontal well systems only and their associated produced volumes and chemical composition. The total dissolved solids for these selected flowback wells have also been included in Table 3. It should be kept in mind that the backflow water not only consists of hydraulic fracturing fluid but also of chemicals that were produced from the geological formation in which the hydraulic fracturing event took place, thus resulting in a mixture of hydraulic fracturing fluid and shale chemical constituents. The volume of water is also a representation of water injected and water present in the shale, which initially depends on the storativity of the shale and the porosity. Most notable of the tables presented here is that there is a number of missing data points, in either the flowback volumes or total dissolved solids concentration values. In some regard this reduces the usefulness of the data but it does give a good indication of expected volumes and salt loading over time.

\begin{tabular}{|c|c|c|c|c|c|c|c|}
\hline & & Hydraulic Fluid (HF) & Cumula & e Volume o & Flowback W & $\operatorname{ter}(\mathrm{FW})$ & \\
\hline Site & Well Type & $\begin{array}{l}\text { Total Volume } \\
\text { (I) }\end{array}$ & $\begin{array}{c}\text { Day } 1^{*} \\
\text { (I) }\end{array}$ & $\begin{array}{l}\text { Day } 5 \\
\text { (I) }\end{array}$ & $\begin{array}{c}\text { Day } 14 \\
\text { (I) }\end{array}$ & $\begin{array}{c}\text { Day } 90 \\
\text { (I) }\end{array}$ & $\% \mathrm{FW} / \mathrm{HF}$ \\
\hline$A$ & Vertical & $6,366,805$ & 628,000 & $1,662,371$ & $2,388,466$ & & 37.5 \\
\hline B & Vertical & $14,979,147$ & 174,091 & $1,714,201$ & $2,180,988$ & $2,844,283$ & 19.0 \\
\hline C & Horizontal & $23,248,077$ & 525,930 & $1,534,545$ & $2,542,366$ & & 10.9 \\
\hline D & Horizontal & $3,361,627$ & 453,750 & $1,284,140$ & $1,580,016$ & $1,778,273$ & 52.9 \\
\hline$E$ & Horizontal & $8,505,821$ & $1,360,931$ & $3,232,212$ & $3,912,677$ & $4,082,794$ & 48.0 \\
\hline $\mathrm{F}$ & Horizontal & $12,400,214$ & 520,206 & $1,721,832$ & $1,960,472$ & $2,768,446$ & 22.3 \\
\hline G & Horizontal & $19,701,865$ & 193,806 & $1,191,292$ & $1,982,731$ & $2,969,406$ & 15.1 \\
\hline $\mathrm{H}$ & Vertical & $5,729,107$ & 634,041 & $2,602,463$ & $3,383,568$ & $5,045,462$ & 88.1 \\
\hline K & Horizontal & $11,252,167$ & 914,336 & $1,274,442$ & $1,506,087$ & & 13.4 \\
\hline$M$ & Horizontal & $15,770,745$ & $2,610,412$ & $2,851,437$ & $3,135,707$ & & 19.9 \\
\hline $\mathrm{N}$ & Vertical & $1,818,020$ & 386,657 & 438,646 & 483,798 & 562,020 & 30.9 \\
\hline $\mathrm{O}$ & Horizontal & $15,375,026$ & 815,764 & $3,052,874$ & & & 19.9 \\
\hline $\mathrm{Q}$ & Vertical & $3,750,987$ & 209,068 & 568,698 & 809,245 & & 21.6 \\
\hline S & Vertical & $2,616,931$ & 332,919 & $1,245,189$ & $1,485,736$ & $1,704,821$ & 65.1 \\
\hline
\end{tabular}

Table 2. Reported hydraulic fracturing and flowback volumes from Hayes report [27]. 


\begin{tabular}{|c|c|c|c|c|c|}
\hline Site & Day 0* & Day 1 & Day 5 & Day 14 & Day 90 \\
\hline C & 719 & 24,700 & 61,900 & 110,000 & 267,000 \\
\hline D & 1,410 & 9,020 & 40,700 & & 155,000 \\
\hline $\mathrm{E}$ & 5,910 & 28,900 & 55,100 & 124,000 & \\
\hline $\mathrm{F}$ & 462 & 61,200 & 116,000 & 157,000 & \\
\hline G & 1,920 & 74,600 & 125,000 & 169,000 & \\
\hline K & 804 & 18,600 & 39,400 & 3,010 & \\
\hline M & 371 & & & 228,000 & \\
\hline O & 2,670 & 17,400 & 125,000 & 186,000 & \\
\hline
\end{tabular}

Table 3. Concentration of Total Dissolved Solids from Selected Sites (mg/l).

The average chemical salt loading in the return water was in excess of a $95000 \mathrm{mg} / \mathrm{l}$ (Figure 6). Considering these values an expected salt load produced from a single well would be in the range of 241 tons of material, which would require adequate disposal regulations since the waste would contain materials classified as harmful to the environment ( $\mathrm{Sr}, \mathrm{Ba}, \mathrm{Li}, \mathrm{Cl}$ and $\mathrm{Br}$ ). A further consideration in processing the material would be the quantity of salts produced during a specified time period. Data reported by Hayes [27] were analysed to derive salt loads at reported day intervals at which chemical sample analysis were performed (Table 4). From the data presented the salt loading values vary considerably over production time and that no singular analysis can be used to determine when the most salt from the hydraulic fracturing well would be produced. This is due to different geologies as well as hydrogeological factors (porosity, permeability and water content of the formation). Secondly, salt loads vary from as little as 45 tonnes to 439 tonnes at 90 day, indicating that a significant quantity of salts is produced from each of the respective wells. The cumulative salts produced from these six wells are in the order of 1920 tonnes which should be disposed of in an environmentally sound methodology.

In order to determine the 90 day values, a linear regression method was used to fit the data to a logaritmic function. Cumulative salt loading values were used since it was composed of both the flowback volume and total dissolved solids (TDS) value. It was assume in the calculations that the decrease in flow volume would continue to follow a logaritmic function, as would typically be expected from a production well. The salt loading (TDS) had a similar pattern and could be expcted to increase in the same methodology for the 90 day time period. If these values are not considered for the 90 day production then the 14 day production in salt loading is expected to be 1350 tonnes at an average of 169 tonnes. 


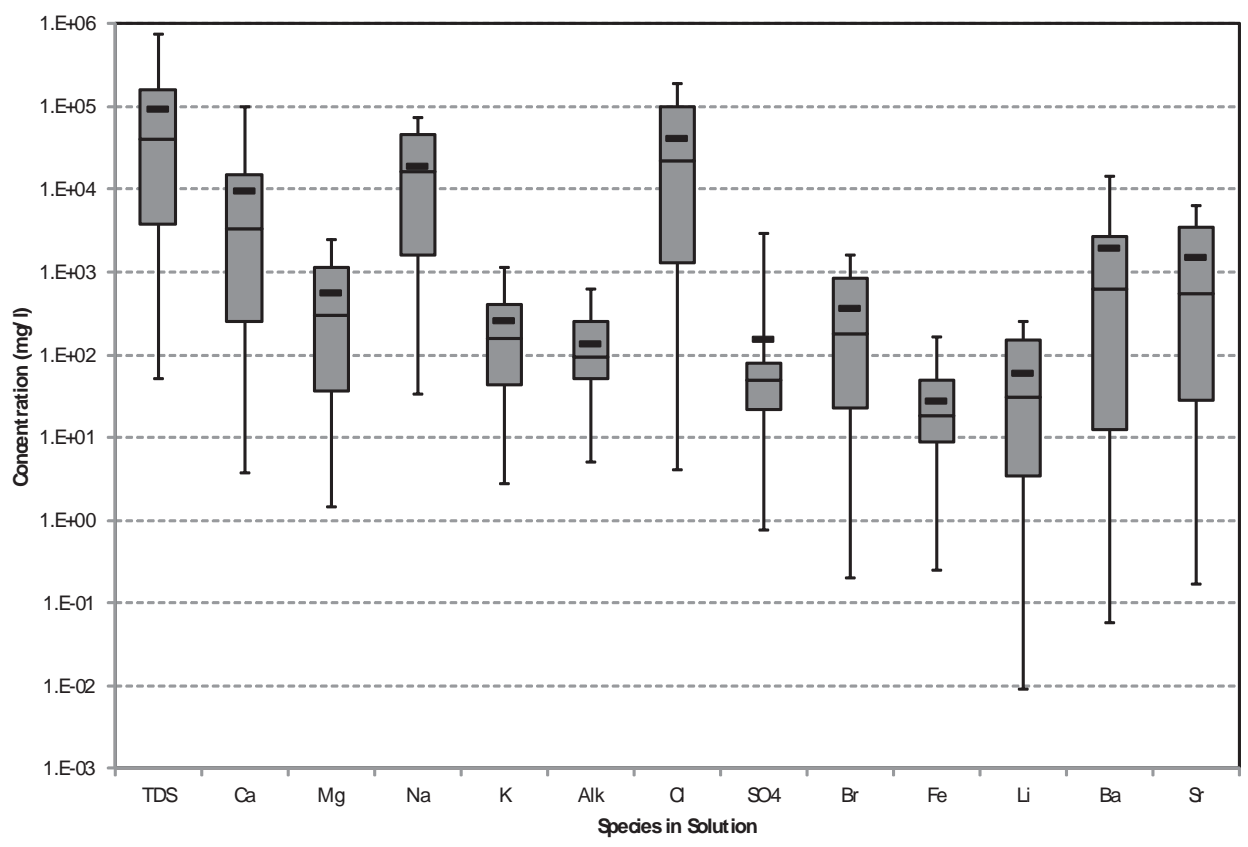

Figure 6. Box-and-Whisker diagram presenting the average distribution of sampled sites chemical components.

\begin{tabular}{llllll}
\hline & Cumulative salt load & \multicolumn{5}{c}{ Day } \\
\hline Site & 0 & 1 & 5 & 14 & 90 \\
\hline C & (tons) & (tons) & (tons) & (tons) & (tons) \\
\hline D & 17 & 13 & 75 & 186 & $287^{*}$ \\
\hline E & 5 & 4 & 38 & 65 & 96 \\
\hline F & 50 & 39 & 142 & 227 & $353^{*}$ \\
\hline G & 6 & 32 & 171 & 209 & $349^{*}$ \\
\hline K & 38 & 14 & 139 & 273 & $439^{*}$ \\
\hline $\mathrm{M}$ & 9 & 17 & 31 & 32 & $45^{*}$ \\
\hline O & 6 & 14 & 294 & 65 & \\
\hline
\end{tabular}

Table 4. Cumulative salt loads in tons at a specific day for the respective sites. Values with * indicate projected values. 
Since all of the data which is available from hydraulic fracturing events are based on the Marcellus shale areas in the USA a question arose to the effect as how the Karoo shales compare the Marcellus shale. In order to investigate this question, Whitehill samples were collected from the Geological Department at the University of the Free State and subjected to a leaching test in acid. The results obtained are reported in Table 5 under the heading of Karoo. To draw a comparison between the shales the average chemical analysis of produced water from the Hayes report [27] and average composition of shales [35] were included. Due to different analysis methodologies and production environments these values could not be directly compared, instead ratios of the major elements were used to determine if a possible correlation did exist (Table 6). In general a good correlation existed between the reported sample compositions in the Hem and Karoo data, with all results of the ratios within the same order when compared to each other. In contrast the Hayes report differed notably in the $\mathrm{Ba} / \mathrm{Ca}, \mathrm{Ba} / \mathrm{Li}$ and $\mathrm{Ba} / \mathrm{Mg}$ ratios which could possibly indicate that the use of hydraulic fracturing additives might have changed the chemical character of the produced water or that a substantial difference exists in the geological formation. Interestingly the remainder of the ratios are within an order of each other, especially the $\mathrm{Ba} / \mathrm{Sr}, \mathrm{Ba} / \mathrm{Na}$ and $\mathrm{Sr} / \mathrm{Na}$ ratios. This could possibly indicate that similar chemical properties in the produced water can be expected from the Karoo type shales in which the hydraulic fracturing events will take place. However, it should be kept in mind that without hydraulic fracturing field data these values can only be assumed to indicate possible chemical species. This clearly indicates that a test site should be established to determine the quantity and quality of the backflow water over an extended time period.

\begin{tabular}{ccccccccc}
\hline Source & \multicolumn{7}{c}{ Element $(\mathbf{m g} / \mathbf{l})$} \\
\hline & $\mathrm{Ba}$ & $\mathrm{Ca}$ & $\mathrm{Fe}$ & $\mathrm{Li}$ & $\mathrm{Sr}$ & $\mathrm{Mg}$ & $\mathrm{K}$ & $\mathrm{Na}$ \\
\hline Hem $^{1}$ & 250 & 22500 & 38800 & 46 & 290 & 16400 & 24900 & 4850 \\
\hline Hayes $^{2}$ & 1552 & 8451 & 64 & 70 & 1650 & 728 & 237 & 24043 \\
\hline Karoo $^{3}$ & 2.7 & 2400 & 770 & 1 & 3.2 & 308 & 50 & 50 \\
\hline
\end{tabular}

1. Hem report USGS [35]; 2. Hayes report GTI [27]; 3. Karoo Sample leached in lab with HCl acid

Table 5. Reported composition of shale samples obtained from various sources.

\begin{tabular}{cccccccc}
\hline Source & \multicolumn{7}{c}{ Element $(\mathbf{m g} / \mathbf{l})$} \\
\hline & $\mathrm{Ba} / \mathrm{Sr}$ & $\mathrm{Ba} / \mathrm{Ca}$ & $\mathrm{Ba} / \mathrm{Li}$ & $\mathrm{Ba} / \mathrm{Mg}$ & $\mathrm{Ca} / \mathrm{Mg}$ & $\mathrm{Ba} / \mathrm{Na}$ & $\mathrm{Sr} / \mathrm{Na}$ \\
\hline $\mathrm{Hem}^{1}$ & 0.86 & 0.01 & 5.43 & 0.02 & 1.37 & 0.05 & 0.06 \\
\hline Hayes $^{2}$ & 0.94 & 0.18 & 22.17 & 2.13 & 11.61 & 0.06 & 0.07 \\
\hline Karoo $^{3}$ & 0.84 & 0.01 & 2.70 & 0.01 & 7.79 & 0.05 & 0.06 \\
\hline
\end{tabular}

1. Hem report USGS [35]; 2. Hayes report GTI [27]; 3. Karoo Sample leached in lab with HCl acid

Table 6. Ratios of chemical compositions from reported shale samples. 
A recent sampling event took place at the Soekor core holes. Currently, the data set is limited and contains both the Soekor core hole data and surrounding well water. Interestingly, one of the core holes produced natural gas that could be ignited. The data is presented in Figure 7 in association with the Hayes report [27] data. Soekor data points are indicated as triangles, with SA 1, 5 and 7 representing samples from Soekor core holes. Sample data SA1 amd SA5 has a similar water type than that observed for the Hayes data set, which would indicate a highly mineralised water type. The main difference in the produced water is that the Soekor core holes have a reduced total dissolved solids content of approximately 6500-7200 mg/l. The third Soekor core hole water data (SA7) clearly has a $\mathrm{Na} / \mathrm{K}-\mathrm{HCO}_{3}$ water type and a TDS of $440 \mathrm{mg} / \mathrm{l}$, indicating the presence of a surface aquifer interaction or a recharge mechanism that is introducing freshwater into the system. Furthermore, it is unsure at this stage if the anulus of the bore is still intact or if short-circuiting is taking place at the site. The data presented is only preliminary and further data sets is required to fully characterise these sites.

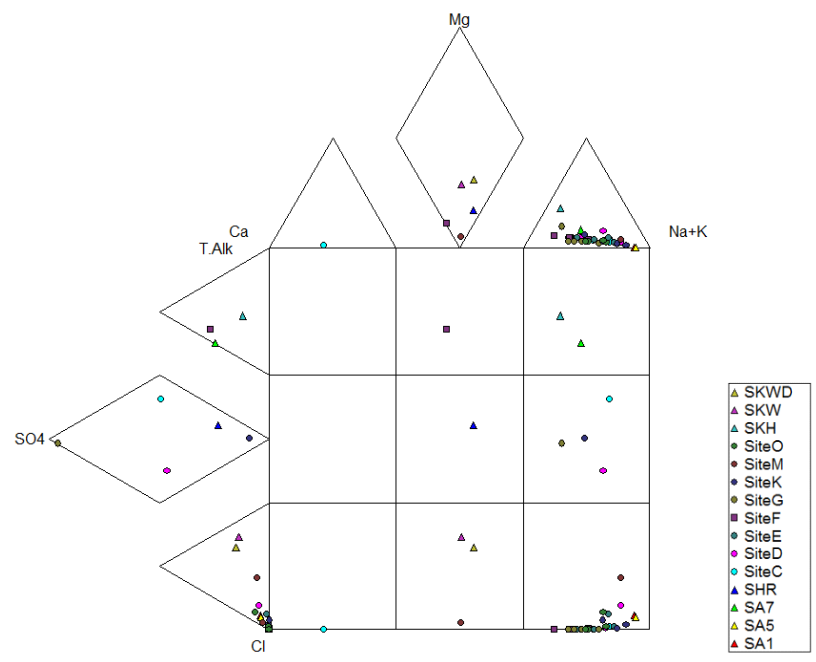

Figure 7. Expanded Durov diagram illustrating the different water types characterised from the Marcellus [27] and Soekor sites.

The Soekor core bores have been abandoned for nearly 40 years and there is still evidence that relatively high salinity water is produced from these sites. The rate of water production is relatively low compared to the data presented by Hayes [27], but as the production rate of water decreases at the sites it is currently unclear if there is still a hydraulic pressure that could produce water at surface. In the instance of the Soekor sites it does seem likely that recharge is occuring and that unless these holes are adequately sealed, a continuous discharge of water and gas might be possible. 


\subsection{Environmental impacts of hydraulic fracturing}

The concerns over hydraulic fracturing centre on a few main issues (Figure 8): (1) migration of gas, (2) migration of fracturing fluids, (3) water use, (4) management of produced water, (5) surface spills and (6) identification of chemical additives. Each of these issues will be addressed in the following numbered sections, it is a summary of best practice guidelines to prevent uncontrolled releases of hydraulic fracturing fluid into the environment or to protect the environment within a reasonable limit of practice.

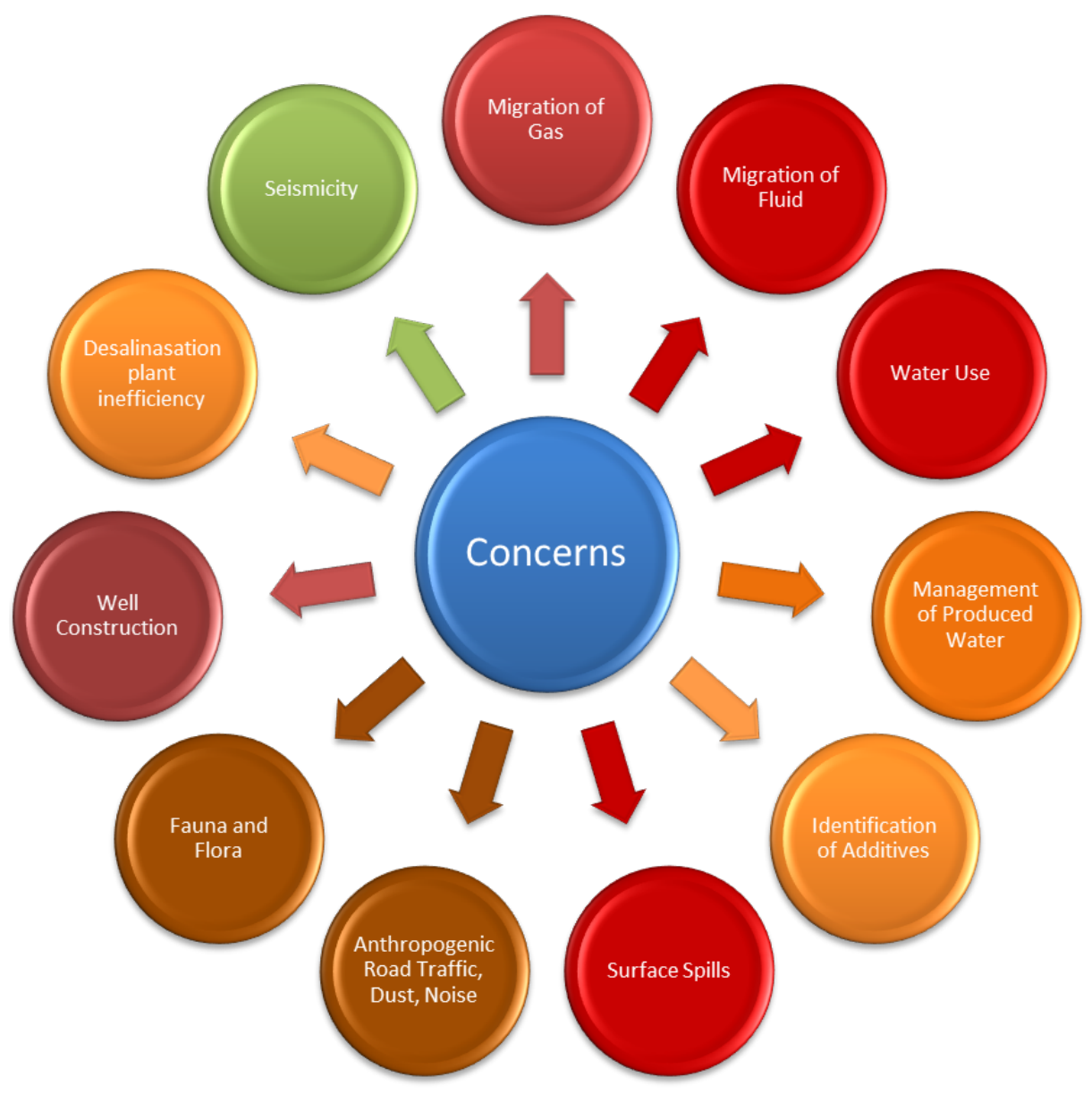

Figure 8. Main concerns regarding impacts of hydraulic fracturing on the environment.

Michigan's laws and rules effectively protect water and other natural resources as well as public health and safety from potential adverse effects of hydraulic fracturing. The Department of Environmental Quality (DEQ) has more than 50 staff employed in enforcing these state 
requirements. To date, only a few productive Utica/Collingwood Shale gas wells have been drilled in Michigan and the potential for more extensive development is unknown; however, the DEQ is taking a proactive approach in addressing large-scale hydraulic fracturing as well as other issues associated with deep shale gas development.

1. Migration of gas or fracture fluids. A major concern in natural gas development is the prevention of migration of gas or other fluids out of the reservoir and into overlying strata, particularly fresh water aquifers. In cases where this has occurred, it has been the result of well construction problems and not of hydraulic fracturing itself [36; 37]. At depths of about 610 meters or less, fractures propagate horizontally due to the natural stress regime of the rock. This confines the fractures to the gas reservoir. At greater depths, fractures may propagate vertically; however, characteristics of overlying rock layers prevent fractures from extending above the top of the gas reservoir. The installation of steel pipe ("casing"), encased in cement, is key to preventing migration of gas or fluids. Michigan regulations require that each oil and gas well have a casing and cementing plan that will effectively contain gas and other fluids within the wellbore, whether related to fracturing or not. Surface casing must be set a minimum of 35 meters into the bedrock and 35 meters below any fresh water zones and cemented from the base of the casing to the ground surface. Before fracturing or other operations can take place to complete a well for production, an additional string of production casing must be set to the depth of the reservoir and cemented in place. Depending on depth, additional protective casing may be required. To provide additional protection for aquifers and well integrity, the DEQ imposes a permit condition for wells in shallow reservoirs prohibiting hydraulic fracturing within 15 meters of the base of the surface casing. In addition, Instruction 1-2011 requires reporting of volumes, rates, and pressures (including pressure immediately outside of the pipe used to inject the fracturing fluid). Also, DEQ staff check wells in the vicinity to assure there are no wells or other features that could serve as conduits for unwanted movement of fracturing fluids.

2. Water use. A fracture treatment of a typical Antrim gas well requires about $189 \mathrm{~m}^{3}$ of water. In the emerging Utica/Collingwood Shale gas development, the amount of water needed to fracture a horizontal well may be up to $18927 \mathrm{~m}^{3}$ or more. To put this in perspective, $18927 \mathrm{~m}^{3}$ is the volume of water typically used by eight to ten acres of corn during a growing season. Withdrawal of water for oil and gas operations is exempt from the requirements of Michigan's water withdrawal statute; however, Instruction 1-2011 requires the operator to perform the same water withdrawal impact assessment as any other user of large volumes of water. It also requires installation and monitoring of an observation well if there is a freshwater supply well within one-quarter mile. The DEQ will not approve a withdrawal of water for hydraulic fracturing if it is likely to cause a significant adverse impact to groundwater or surface water.

3. Management of produced water. Proper management of produced water is essential in protecting public health and the environment. In Michigan, produced water must be managed. Hydraulic Fracturing and disposed of according to strict rules specifically applying to those fluids. The fluids must be contained in steel tanks and transported to 
disposal wells where they are injected into deep rock layers that are isolated from fresh water supplies. The disposal wells are licensed by both the DEQ and the U.S. Environmental Protection Agency, and must be tested periodically to assure well integrity. Instruction 1-2011 requires reporting of the volume of flowback water recovered after a hydraulic fracturing operation.

4. Surface spills. Spills of chemical additives or flowback water can have adverse environmental or public health impacts. Michigan requires secondary containment under tanks, wellheads, and other areas where spills may be most likely. If a spill does occur, it must be reported immediately to the DEQ, and all spills must be promptly recovered and cleaned up according to strict requirements.

5. Identification of chemical additives. Instruction 1-2011 requires oil and gas operators to provide to the DEQ copies of all Material Safety Data Sheets (MSDSs) for additives used in hydraulic fracturing. The MSDSs include information on physical characteristics, toxicity, health effects, first aid, reactivity, storage, disposal, protective equipment, and spill response. The DEQ will post the MSDSs on the Department's web site for public review. While the details on some of the chemical compounds used in hydraulic fracturing are exempted from disclosure on the MSDSs under federal law, the MSDSs will provide enough information for the DEQ to track and monitor spills.

The regulations enforced in Michigan was designed for the state specifically, in the instance of South Africa the following key differences will need to be considered.

- It most likely will not be possible to dispose of brine by re-injection into deep wells unless an exception in relation to the Water Act is obtained. This will introduce another issue which is disposal of solids and brines that is produced from water purification processes.

- The volume of material produced over the lifetime of a well field might require some engineering adaptation and/or disposal in dedicated waste storage facility constructed just for this purpose. It is still an open question as to how this will be managed.

- On the issue of water use, there is currently enough usable water available to proceed with hydraulic fracturing in the Karoo basin; but it will require planning and development of small scale well fields to abstract adequate volumes.

- Desalination plant efficiencies will need to be increased as the systems are currently sensitive to inflow water quality. It will most likely be associated with a multi-stage facility to remove organics (BTEX, PAHs) from the produced water and total dissolved salts. The composition of the salts is assumed to be mostly $\mathrm{Na} / \mathrm{Cl}$ but it is expected that $\mathrm{Ca}, \mathrm{Fe}$ and $\mathrm{Mg}$ salts will also be present. The presence of Fe salts might also pose interesting processing challenges for these plants.

- The presence of dolerite formations and thermal springs indicate that there might be a possible upward migration pathway for contamination migration. The probability of this occurring in the vicinity of the well field cannot be ruled out; especially if control measures and well field integrity is not measured over the lifetime of the well. 
- In addition post-closure monitoring should be conducted to ensure that well failure does not cause upward migration of contaminants (i.e. Soekor sites).

\section{Conclusions}

South Africa has in the past been heavily dependent on its rich coal resources to supply it of electricity and fuel; with the discovery of an unconventional terrestrial gas resource it is currently entering a new age of energy independence. The development of this resource has put a strain on local communities due to fears of contaminated surface water and groundwater resources. The area currently being investigated, has both a historical and national significance and emotions are running high. Due to the sensitivity of South Africans regarding the Karoo, a great deal of care is required when gas exploration and eventual development occurs in this area. Key concerns is that the environment will be impacted to such an extent that it will be irrevocably changed. The geology of the area is to a certain extent complex and has dolerite sills and dykes which intrude the country rock. However, the Ecca formations of the Karoo has a considerable carbon content and suitable thickness to make it an ideal target for shale gas development. In this paper the process of hydraulic fracturing have been investigated from a hydrochemical perspective. Firstly, the composition of hydraulic fracturing fluids and the possible risks it pose to the surface and subsurface systems. Secondly, backflow water was evaluated for the Marcellus Shale since no current hydraulic fracturing program has been initiated in South Africa to target the Ecca shale formations. A summary of the key parameters were discussed as well as the production of flowback water and salt loading. Issues relating to salt loading were mainly related to treatment plants and the ability to effectively dispose of the produced brines and salts. A limited set of samples were incorporated into this paper from the Soekor core holes, and similar trends in water type was observed for both the Soekor sites and Marcellus samples.

Environmental impacts due to hydraulic fracturing activities were discussed. Due to South Africa's recent introduction to unconventional gas development a number of important regulatory processes does not exist, i.e. well and site inspectors. The state of Michigan's proactive approach to regulating shale gas development addressed most of the issues which will be prevelent in the South African regulators mind. Finally, key differences between the regulatory environments were presented as well as unique challenges that faces South Africa in developing the unconventional gas resource.

\section{Acknowledgements}

We would like to acknowledge the University of the Free State and Water Research Commission of South Africa for funding. Dr. L. Chevallier for the geological information and assistance in strata characterisation. 


\section{Author details}

G. Steyl ${ }^{1,2}$ and G. J. van Tonder ${ }^{3}$

1 Golder Associates Pty Ltd, Milton, Queensland, Australia

2 Department of Chemistry, University of the Free State, South Africa

3 Institute for Groundwater, University of the Free State, South Africa

\section{References}

[1] Twine, T, Jackson, M, Potgieter, R, Anderson, D, \& Soobyah, L. Karoos Shale Gas Report: Special Report on Economic Considerations Surrounding Potential Shale Gas Resources in the Southern Karoo of South Africa. In, (Econometrix), 76. Econometrix Park, 8 West Street, Houghton, Johannesburg, 2198; (2012).

[2] Steyl, G, Van Tonder, G. J, \& Chevallier, L. State of the Art: Fracking for Shale Gas Exploration in South-Africa and the Impact on Water Resources. In, (Commission W.R.), 96. Pretoria; (2012).

[3] Xiphu, M. R, Mills, S. R, Chevallier, L, Marot, J, Mkhize, M, Motloung, T, Ngesi, P, Okonkwo, A, Msmart, M, Solomons, M, Tiplady, A, \& Van Wyk, E. Report on Investigation of Hydraulic Fracturing in the Karoo Basin of South Africa. In, (Resources D.o.M.), 96. 70 Meintjies Street, Sunnyside: Department of Mineral Resources; (2012).

[4] Howard, G. C, \& Fast, C. R. Hydraulic Fracturing.. In Monograph of the Henry L. Doherty Series. New York: Society of Petroleum Engineers; (1970).

[5] Montgomery, C. T, \& Smith, M. B. Hydraulic Fracturing-History of an Enduring Technology. Journal of Petroleum Technology 62: 16; (2010).

[6] Van Poolen, H. K, Tinsley, J. M, \& Saunders, C. D. Hydraulic Fracturing-Fracture Flow Capacity Vs. Well Productivity, Trans. AIME (1958). , 213, 91-95.

[7] Rowsell, D. M, \& Swardt, A. M. J. Diagenesis in Cape and Karoo Sediments, South Africa, and Its Bearing on Their Hydrocarbon Potential. Trans. Geol. Soc. S. Afr. (1976). , 79, 81-145.

[8] Tissot, B. P, \& Welte, D. H. Petroleum Formation and Occurrence. New York: Springer-Verlag; (1984).

[9] Hayden, J, \& Pursell, D. The Barnett Shale, Visitors Guide to the Hottest Gas Play in the Us. In, (INC P.E.Houston, Texas: Institutional Research; (2005). , 52. 
[10] De Wit, M. J. The Great Shale Debate in the Karoo. South African Journal of Science 107: 9; (2011).

[11] Veevers, J. J, Cole, D. I, \& Cowan, E. J. Southern Africa: Karoo Basin and Cape Fold Belt. In Permian-Triassic Pangean Basins and Foldbelts Along the Panthalassan Margin of Gondwanaland, (Veevers J.J. and Powell C.M.). Boulder, Colorado: Geological Society of America; (1994).

[12] Gradstein, F. M, Ogg, J. G, Smith, A. G, Bleeker, W, \& Lourens, L. J. A New Geologic Time Scale, with Special Reference to Precambrian and Neogene. Episodes (2004). , $27,83-100$.

[13] Viljoen, J. H. A. Tierberg Formation. In Catalogue of South African Lithostratigraphic Units, (Johnson M.R.). Pretoria: South African Committee for Stratigraphy, Government Printer; (2005).

[14] Cole, D. I, \& Mclachlan, I. R. Oil Shale Potential and Depositional Environment of the Whitehill Formation in the Main Karoo Basin. Geological Survey of South Africa; (1994).

[15] Cole, D. I, \& Christie, A. D. M. A Palaeoenvironmental Study of Black Mudrock in the Glacigenic Dwyka Group from the Boshof-Hertzogville Region, Northern Part of the Karoo Basin, South Africa. In Earth's Glacial Record. International Geological Correlation Project 260, (Deynoux M., Miller J.M.G., Domack E.W., Eyles N., Fairchild I.J. and Young G.M.). Cambridge: Cambridge University Press; (1994).

[16] Cole, D. I, \& Basson, W. Whitehill Formation. In Catalogue of South African Lithostratigraphic Units, (Johnson M.R.). Pretoria: South African Committee for Stratigraphy, Government Printer; (1991).

[17] Cole, D. I. Prince Albert Formation.. In Catalogue of South African Lithostratigraphic Units, (Johnson M.R.). Pretoria: South African Committee for Stratigraphy. Pretoria: Government Printer; (2005).

[18] Johnson, M. R, Van Vuuren, C. J, Visser, J. N. J, Cole, D. I, Wickens, H. D. V, Christie, A. D. M, \& Roberts, D. L. and B. L.G. Sedimentary Rocks of the Karoo Supergroup. In The Geology of South Africa, (Johnson M.R., Anhaeusser C.R. and Thomas R.J.). Johannesburg/Pretoria: Geological Society of South Africa/Council for Geoscience; (2006).

[19] Branch, T, Ritter, O, Weckmann, U, Sachenhofer, R. F, \& Schilling, F. The Whitehill Formation-a High Conductivity Marker Horizon in the Karoo Basin. South African Journal Geology (2007). , 110, 465-476.

[20] GA. Background Information Document and Invitation to Comment. In Proposed South Western Karoo Bsoin Gas Exploration Project, (B.V. S.E.C.). 2011.

[21] Dondo, C, Chevallier, L, Woodford, A. C, Murray, R, \& Nhleko, L. Flow Conceptualisation, Recharge and Storativity Determination in Karoo Aquifers, with Special Em- 
phasis on Mzimvubu-Keiskamma and Mvoti-Umzimkulu Water Management Areas in the Eastern Cape and Kwazulu-Natal Provinces of South Africa. In Research Reports. Pretoria: Water Research Commission of South Africa; (2010).

[22] Rowsell, D. M, \& Connan, J. Oil Generation, Migration and Preservation in the Middle Ecca Sequence near Dannhauser and Wakkerstroom. In Some Sedimentary Basins and Associated Ore Deposits of South Africa. Special Publication of the Geological Society of South Africa, (Anderson A.M. and Van Biljon W.J.). Pretoria: Geological Society of South Africa; (1979).

[23] Steyl, G. Estimation of Representative Transmissivities of Heterogeneous Aquifers. In Institute for Groundwater Studies, 132. Bloemfontein: Free State University; (2012).

[24] Murray, R, Baker, K, Ravenscroft, P, Musekiwa, C, \& Dennis, R. A Groundwater Planning Toolkit for the Main Karoo Basin. In Research Reports. Pretoria: Water Research Commission of South Africa; (2012).

[25] Kent, L. E. The Thermal Waters of the Union of South Africa and South West Africa. Transactions of the Geological Society of South Africa (1949). , 52, 231-264.

[26] Viljoen, J. H. A, Stapelberg, F. D. J, \& Cloete, M. Technical Report on the Geological Storage of Carbon Dioxide in South Africa. In. Pretoria: Council for Geoscience South Africa; (2010).

[27] Hayes, T. Sampling and Analysis of Water Streams Associated with the Development of Marcellus Shale Gas. In, 356. Des Plaines, IL 60018: Marcellus Shale Coalition; (2009).

[28] HalliburtonHydraulic Fracturing: Fluids Disclosure. In, Description of Hydraulic Fracturing and Fluids Used in the Process 28 February. (2013).

[29] FracFocusFind a Well. In, Find a Well (Hydraulic Fracturing)28 February. (2013).

[30] SWEPILPHydraulic Fracturing Fluid Product Component Information Disclosure. In. Erikson 448 4H; (2012).

[31] Waxman, H. A, Markey, E. J, \& Degette, D. Chemicals Used in Hydraulic Fracturing. In, (Representatives H.o.). Washington, USA: US Government; (2011).

[32] EIDA Fluid Situation, Typical Solution Used in Hydraulic Fracturing. In DOE, GWPC: Modern Gas Shale Development In the United States: A Primer ((2009). Energy Indepth; 2010.

[33] Fortson, L. A, Yatzor, B, \& Bank, T. Physical and Chemical Associations of Uranium and Hydrocarbons in the Marcellus Shale. In Proceedings of' Northeastern (46th Annual) and North-Central (45th Annual) Joint Meeting. Geological Society of America., 60 
[34] DOOGMC Department Office of Oil and Gas Management Compliance Report. In. Pennsylvania: Pennsylvania Department of Environmental Protection; (2013).

[35] Hem, J. D. Study and Interpretation of the Chemical Characteristics of Natural Water. In, Contract Alexandria: United States Geological Survey; (1985). (2254)

[36] Bybee, K. Cement Design for the Life of the Well. Journal of Petroleum Technology 54, (2002). , 8(8), 60-61.

[37] Roshan, H. R. S.S. A Fully Coupled-Poroelastic Analysis of Pore Pressure and Stress Distribution around a Wellbore in Water Active Rocks. Rock Mech Rock Eng (2011). , 44, 199-210. 
